\title{
Hysteresis, academic biography, and political field in the People's Republic of Poland
}

\section{Agata Zysiak ${ }^{1}$}

Published online: 15 June 2019

(C) The Author(s) 2019

\begin{abstract}
I enter a debate about state-socialism elite's reproduction and higher education to propose an implementation of Bourdieu's hysteresis effect. I argue that the intelligentsia and the interwar university shaped biographical paths of academics stronger than the political factors, which are usually brought to the forefront by contemporary researchers. I analyse academic biographies shaped by the socialist university and reconstruct a model academic biography in the post-WWII period, in particular, in Poland. I compare it with biographies of professors from working-class and peasant backgrounds, and arrive at the conclusion that the differences are minor. Those who formed a seemingly perfect new intelligentsia were socialized by the traditional academic habitus. A few who entered the new academic world from working class or peasant backgrounds had to embrace the interwar university ethos in order to justify their own merits in belonging. I propose a model of opposite hysteresis vectors to explain tensions between academia and political field.
\end{abstract}

Keywords Academia $\cdot$ Bourdieu $\cdot$ Eastern Europe $\cdot$ Hysteresis $\cdot$ Poland $\cdot$ The socialist university

"[...] the ruse of academic reason, by which the institution leads the teacher to serve it by disposing him to make use of it, ultimately serves a function of social conservation which academic reason cannot recognize." (Bourdieu and Passeron 1990, p. 125)

For over a decade, Pierre Bourdieu's theory has been facing a revival, indicated by the rising number of conferences, debates, and research projects inspired by his intellectual framework (Ollion 2015). Problems of elite reproduction and the education system in

Agata Zysiak

agata.zysiak@uni.lodz.pl

1 Institute of Sociology, University of Łódź, 43/45 Rewolucji 1905 St, 90-255 Łódź, Poland 
state-socialisms had been discussed before using Bourdieu's theory, which provided a useful framework for such analysis (Andreas 2009; Bozóki 1999; Eyal et al. 2000; Tromly 2014; Zarycki 2008). The majority of the existing literature focuses on field analysis and the interplay of capitals, especially in the post-socialist period (Pop 2018), while I propose to examine the state-socialist higher education using a hysteresis as a key-term for interpretation. I enter a debate about state-socialism elite's reproduction and higher education to propose an implementation of a lesser-known element of Bourdieu's theory. A testing ground is found in academic biographies in post-WWII Poland. I compare typical intelligentsia biographies with biographies of les miraculésprofessors from working-class and peasant backgrounds, who were supposed to became a "new intelligentsia" and form a true socialist university.

The Stalinist reform attempted to replace the "old intelligentsia" - both faculty and university students - with new cadres of working-class and peasant background. Despite the changing political and social context, Polish universities nevertheless managed to minimize the real changes. The case study examined here is the industrial city of Łódź where a socialist university was established from scratch in 1945, supported by a wide coalition of leftist faculty. Additionally, this biggest urban center of the postwar years offered a preferable social structure of enrolled students and proletarian traditions. Already by the 1950s, a new generation of scholars entered academia and took agency at universities. The postwar generation was supposed to become a group of true comrades and to build the university-factory for a new era. It did not happen. The aforementioned factors did not prevent reproduction of the traditional academic habitus in the newly defined positions. With detailed analysis of biographical interviews of professors educated in 1940s and 1950s, I argue that both academics from intelligentsia and peasant families adapted to the old habitus.

I explain this phenomenon in terms of a hysteresis effect-a mismatch or disjuncture between habitus and field, or to put it more precisely: dislocation of habitus in a time of field restructuring (Hardy 2012, p. 132; McDonough and Polzer 2012, p. 362). ${ }^{1}$ Using hysteresis as a tool for analysing the construction of the socialist university leads us to examine the change in the academic habitus under the influence of changes in the political field. The postwar political situation enforced transformations in the academic field, imposing a new social structure and economic order. The reforms, the repressions in the time of Stalinism, and even the simple influx of students from the working classes and massification of universities opened new opportunities for academic careers and were supposed to reconstruct the academic habitus. My proposal is not only to examine the process of adaptation of the habitus of academics to the changed rules of the field but also to consider the changing habitus of

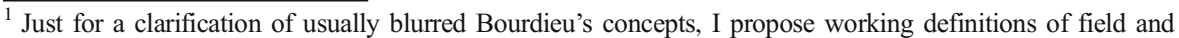
habitus. Stating that the latter is "structured and structuring structure" might not be as instructive as K. Maton's explanation: "Habitus is to Bourdieu's approach what power-knowledge is to Foucault's or coding orientation to Bernstein's - once one has internalized the idea to the extent that it is part of one's way of seeing and thinking about the social world, it becomes second nature"(Maton 2012, p. 64). For explaining the field concept, let me follow a brief definition by D. Swartz: "fields denote arenas of production, circulation, and appropriation and exchange of goods, services, knowledge, or status, and the competitive positions held by actors in their struggle to accumulate, exchange, and monopolize different kinds of power resources (capitals)"(Swartz n.d.)
} 
people entering the academic field because of the changes. I therefore pose the question about the adaptation of les miraculés-people from lower classes, embarking on the path of a university career.

These individuals, who commenced their studies in the late 1940s and the 1950s, entered an academic field that was subject to conflicting logics - traditional and socialist. I claim that the radical project of social reform did not influence the innerruled academia. Furthermore, the contemporary established narrative of a captive university produced by the totalitarian paradigm conceals the highly conservative character of the academic field and its high level of autonomy, especially considering values and the criteria for granting positions to newcomers. A few-decades-old paradigm clash between revisionists and totalitarians took yet another turn after 1989, however this time its main arena of dispute was located not in the United States, but in Eastern Europe and Russia itself. As Stephen Kotkin predicted (Kotkin 1998), a totalitarian hegemony overtook the field of history production in the region and gained support among transition-raised elites (Siegel 2002). Universities as the traditional domain of the intelligentsia still seemed to be regarded as politically dominated by the state, which include two main narratives: either about the captivity of professors or the subjugation of students (Herczyński 2008; Hübner 1992; Palska 1994; ŚwidaZiemba 2003). As a result, one can either speak about terror, the decline of academia, and a loss of autonomy, or about the ideological allure that attracted uneducated masses to support the evil regime. The two are seemingly contrasting yet indeed complementing aspects of the same approach. This totalitarian interpretation offers a vision of an endangered university. Its traditions and values, undermined by political forces that demand the production of specialists, appealed for support for industrial development, and expected the implementation of positive discrimination in favor of youths of working-class origin, etc. In contrast, I claim that the post-WWII period had ambitions to promote modernization, emancipation, and empowerment. I would even argue it had considerable but limited achievements. One of its limits was reforming academia and opening higher education to the masses.

\section{Scale of reforms}

In the interwar period, the universities had a rather conservative profile with respect to both their methodological and political aspects. Antisemitism at universities was just one element of increasingly dangerously ethnic tensions throughout the entire country, reflected in the "reforms" of 1933 and the strengthening of the authoritarian regime. Many leftist intellectuals could not find a place for themselves. Considering the dramatic events of Second World War, profound changes of the Polish borders and social structure, and political shifts, we can call this a time of social revolution. And indeed, the post-WWII opening of higher education was revolutionary, rapid, and massive. A center for reconstruction was located in the industrial city of Łódź. Following the conclusion of the war in 1945, only $30 \%$ of its former citizens remained, but its material structure was well preserved, and together with the influx of internally displaced Poles, it become a temporary, informal capital of the country, welcoming 200,000 newcomers in just the next 3 years. It was also a "magnet for leftist intellectuals"(Connelly 2000, p. 103). Although it had been the second largest city 
after Warsaw since the 1870 s, it had neither previous academic structures nor higher education institutions. The industrial giant was also nicknamed the "red" city because of its tradition of the 1905 Revolution and labor movements. Overall, it seemed a perfect place to build a university for a new era, and one could easily feel and become a part of this change. In contrast to the conservative Jagiellonian University in Cracow or the hegemonic University of Warsaw, the University of Łódź served as a paradigmatic case of the socialist university.

The years 1945-1947 were propitious for utopian thinkers, as everything seemed to be subject to and ready for action and change - the so-called "gentle revolution" when many leftist intellectuals engaged in social reform. However, the academic year 1949/ 1950 was crucial for Polish academia as the central reform of higher education was implemented. Academia was "parametrized" in the Soviet/Fordist style, which meant that all its activities were measurable and countable by Ministry of Higher Education, for example, universities were obliged to respect the assigned quotas of students and graduates. Courses became obligatory, and in opposition to the so-called "aristocratic manner of studying," students were supposed to work similarly to workers in a factory: with almost 8 hours per day of classes, roll-call, and supervision of their efficiency. The first 3 years of study were designed to prepare students for practical tasks, and the additional final 2 years to give the students more advanced skills and the "magister" (master) degree. They were expected to contact a future workplace during their studies in order to obtain work experience. Universities were thus to become part of a production process aimed at training skilled specialists (including humanities training for future teachers and office workers). Censorship was strengthened, international cooperation strictly controlled, and many disciplines - like sociology — were labelled as "bourgeois science" and restricted. These reforms were the fruits of a coalition of unevenly reform-minded state officials, soviet-influenced legislation, and academicians themselves.

Considering statistical data, the war losses also acted against the interwar elite's reproduction and in favor of post-WWII reforms as well as emergence of the "new intelligentsia." Before the Second World War, among the 36 million population of the Second Republic of Poland, only 2460 people held posts as professors, adjunct professors, and assistants ${ }^{2}$ (Szczepański 1963, p. 249), almost 90\% were of intelligentsia or nobility origin (Jaczewski 1987, p. 233; Mycielska 1981, p. 254). During the Second World War, over $16 \%$ of the prewar population lost their lives and $38 \%$ of university professors perished. Already in the 1945/46 academic year, some 55,000 faculty members were employed in as many as thirty-three higher education institutions. By 1949, this figure had risen to sixty-seven, and by 1954 to eighty-four (GUS 1955). The excessively rapid rise in the number of universities and faculty meant that there was a shortage of experienced academic professionals. The figures also show how fast the generational change was. The situation in higher education in the first half of the 1950s might have appeared to have been following the model of transition from the interwar university to the socialist one.

Furthermore, the social structure of student enrollment changed radically, while the education profile and professional opportunities of graduates also transformed. After

\footnotetext{
${ }^{2}$ Professors with habilitation (so-called second $\mathrm{PhD}$ ), adjuncts with $\mathrm{PhDs}$, and assistants working on their dissertations composed the faculty structure in interwar Poland.
} 
completing their degrees, young working-class people became engineers, chemists, teachers, managers, or representatives of the authorities at various levels. Since the governmental education reform, the "shackled" and "captive" academic faculty of the pre-war lineage had the task of educating a "new intelligentsia," including future professors. While political careers and even management positions were relatively open to working-class people, academia served as a testing ground for upward mobility. However, while in the 1951/52 academic year, $77.8 \%$ of accepted candidates completed studies, in the following years, this rate began to drop: in 1955/56, it was $73.4 \%$, and in $1958 / 59,68.2 \%$ (Woskowski 1958, p. 164). In the 1960s and 1970s, there was only an absolute growth of the number of working-class students, along with the general growth of the general number of students.

Throughout the entire period of the People's Poland, there was a relatively strong relationship of parents' education and occupation to education of their children. While the general pool of students was increasing, the disparities remained at a similar level (Domański and Tomescu-Dubrow 2008, p. 46). Every year, the mechanisms of dropping out and sieving affected the social structure. From 20 to $60 \%$ of students quit university after the first year. The share of youth from a peasant background remained the same throughout the entire program while the share of intelligentsia grew, hence, it was primarily working-class people who gave up (Słabek 2001, p. 367). Despite various attempts and quite sophisticated tools and policies democratizing access to education, the PRL's entire modernization project, including year zero, preparatory courses, part-time and evening studies as well as university consultation centers in small towns, was not catching on. Differences in educational aspirations (as well as disbelief in the attainability of the goal), economic factors (expenses at the level of the state and at home), demographics (struggles with adjusting the infrastructure and politics to the fluctuations), inequalities in accessing culture, and oftentimes failed educational policies, continued to shape the selection mechanisms. I strive here to show why this happened.

\section{Bourdieu in Eastern Europe}

Considering that, I argue that the old intelligentsia and interwar university shaped biographical paths of erstwhile academics stronger than the political factors, which are usually brought to the forefront by contemporary researchers. While one can almost got lost in the amount of Bourdieu-inspired scholarship on the post-socialist period, the analysis of the state-socialism and post-WWII reforms are much more limited. Bourdieu himself addresses the problem only once, which defined other approaches (Bourdieu 1998a). The main stakes in the latter debate were brought up by Joel Andreas in his book on communist China, where he argued, against the classic interpretation that of Communist parties as representing the proletariat, that they were actually the vanguard of the intelligentsia (Konrád and Szelényi 1979). Andreas shows that emergence of technocratic socialist class was not an achievement of state-socialism, but a failure of class-levelling efforts, which were abandoned halfway through the process (Andreas 2009, pp. 4-5). Both approaches use a frame of competing 
claims between political and cultural capital and announce a final triumph of the latter. I fully agree, but in contrast to those claims, my argument lies closer to John Connelly's or Benjamin Tromly's works, which focus on intelligentsia and its stubborn reproduction-enforced rather than captivated by political influence (Connelly 2000; Tromly 2014). Similarly to Andreas and to Szelényi (Eyal et al. 2000) I use a theoretical framework proposed by Bourdieu and Passeron (Bourdieu 1988, 1989, 1998b; Bourdieu and Passeron 1979, 1990), however the Polish case differs profoundly from, for example,the Chinese one. What is specific for Poland, and partly for the Central and Eastern Europe, is, on the one hand, the social revolution of WWII that changed the social structure and modified the cultural hegemony. It rebuilt the social imaginary, disturbed the cultural domination of the upper classes, and enforced higher education reforms geared towards its democratization. On the other hand, the regional specificity includes the role of the intelligentsia and its ethos (Zarycki 2008), in particular the strong influence of the post-noble Warsaw-based intelligentsia, which hegemonized Polish national culture, and a vision of history from the Russian Partition lens (Jałowiecki 1996, p. 36). This intelligentsia heritage was shaping intellectual elites in the interwar period and consequently the post-WWII formation of universities. I interpret the triumph of cultural capital rather as the intelligentsia reproduction and see academic field as almost unaffected by political capital. Conclusions derived from my research suggest that the triumph of cultural capital was not happening along the agenda of political field, but against it. To establish this, I offer a double vector hysteresis model based in the analysis of academic biographies.

Hysteresis, a term borrowed from the language of physics, is connected to the relationship between field and habitus, and it is crucial for understanding social change. It appears in a few relevant works (Bourdieu 1984, 1999, 2010), yet without being defined precisely. In Distinction, Bourdieu refers to hysteresis as simply meaning "lack." This is a disharmony between the conditions of acquisition and those of using the rules of the field, for example, attributing to devalued titles values to which they are no longer eligible, as in the case of noble titles (Bourdieu 1984, p. 161). The crux of every change in social practice is hysteresis, or rather overcoming it - this is the non-reducible element of the relationship between habitus and field (Susen and Turner 2013, pp. 7880). In Pascalian Meditations, Bourdieu again writes that hysteresis is the inertness of habitus, occurring when people are subject to contradictory conditions. It is the inclination to sustain structures corresponding to the conditions in which they were formed, and it takes place, for example, during rapid transfers in the social structure.

This is therefore the most important concept connected to social change or disturbance of the relationship between habitus and field. When the correspondence between them ceases, the time of crisis follows (Bourdieu 2000). When the structures of fields change and the existing habitus of individuals inherited from the previous balance of powers cease to fit the situation, the result is the hysteresis effect. This is a structural delay between the possibility and the dispositions, noticeable, for instance, in opportunities not taken, the impossibility of thinking certain events in a way that is later obvious. The change in 
structures does not translate directly into a change in human behaviours, and this effect of delay and persistence of effects despite the non-existence of the causes is hysteresis. As a result of learned schemas, feeling at home, aversion to and failure to understand change, humans are inclined to stick with what they are accustomed to. The field has changed, but the expectations and horizons of possibilities of the actors dealing in it mean that they are unable to make use of, or even recognise, this change. This is the moment of social crisis and re-structuralisation of the field (Hardy 2012, p. 132). Hysteresis is therefore a tool of thinking change, transformation of a field, and the subjective nature of changes - an individual response or change in habitus. It therefore occurs at many levels: in the case of children in the working classes entering universities, for example, but also in that of pre-war professors tasked with building the socialist university.

According to Bourdieu, it is the representatives of higher classes who find it easier to make use of changes and adapt to them-their competences and networks allow them to recognise the situation and fit in more quickly. The result of this is that people of success achieve success, while the lower classes are those afflicted most strongly with the inertia of the habitus (Bourdieu 2000, p. 161; Bourdieu and Passeron 1979, p. 135). The dispositions of these people become dysfunctional, leading to greater lack of fit in the field. Yet another example of the hysteresis effect also shows the reverse possibility of loss of agency by people with higher positions in the field as well as less privileged people demonstrating better adaptation to the changes in it. This was because, during the period of higher education reform in France, the middle generation of academic faculty accumulated cultural capital according to the "old principles," and the logic in place for decades in the academic field. They did not perceive the opportunities (and thus threats) associated with the "massification" of education, and their safe positions were occupied by younger, more entrepreneurial graduates geared towards new values and criteria of the field. The younger generation was able to recognise the new possibilities and quickly adapted to the changes, without bearing the burden of the costs that came with acquiring a position according to the principles ruling before higher education was opened to the masses (Hardy 2012, p. 138).

A similar mechanism was at play in the first post-war years at Polish universities. Those who could least fit the academic field in the interwar years - too liberal or leftist, opposing anti-Semitic excesses and feudal customs, and consigned to marginal institutions such as the Free Polish University-were the quickest to find a place for themselves in the post-war turmoil and began to build their own institutions. Then, to capture the socialist academic reform, we observe a top-down change in the rules of the academic field. New criteria were introduced, along with new rules of advancement and new objectives, but the traditional habitus of academics remained relatively unchanged. The hysteresis effect therefore operated at two levels and in contrasting directions. The first level was the adaptation of the academic field to political changes and the simultaneous opposition of the pre-war academic habitus, the aspiration to rebuild the interwar university. The changes on this level excluded many prewar professors from institutional life; enabled careers supported by political 
capital, and finally opened huge opportunities to the working classes as the new intelligentsia. At the same time, though, the hysteresis effect operated within the academic field, with its vector pointing in the opposite direction. Whereas the delayed reaction of the habitus to the changes in the social field continued, the doxa of the academic field remained unchanged, as an enclave of elements of the former order. People entering the field because of political changes and wishing to occupy positions within it were also affected by a reverse hysteresis effect: following their advancement, they were looking for paths of adaptation and were under the strong influence of the pre-war academic habitus. The vectors of these forces were therefore contradictory.

\section{The academic biography}

Every individual biography is characterised by its trajectory, defined by the rules of the field, dispositions, and reproduction. The course of an individual biography can even be used to measure social inequalities, just as one can do so by estimating the probabilities of children from various social backgrounds passing through the successive stages of education. It is not class origin that corresponds directly to social inequalities, but the pertinent educational career. Therefore, the histories of school careers provide excellent material for studying the social paths of biographies. It was for this reason that I chose biographies as the main research material for my analysis.

The autobiographies I selected for careful analysis were those by professors of the University of Łódź born in the 1920s and 1930s only. Despite 30 narrative interviews gathered by a research team, another 32 autobiographies come from edited volumes published in the 1990s and 2000s by the Łódź Scientific titled "My Path to Academia" (Moja droga do nauki vol.1-7, 1996-2013). An additional context was provided by publications containing interviews with professors from Cracow and Warsaw, but also other cities. In the entire set of autobiographies and narrative interviews, which for simplicity's sake I group together and call biographies; just a few belonged to people from the working classes. In total, of 1516 pages of autobiographies of 59 professors (some were interviewed and wrote an autobiography), 52 fulfilled the requirements adopted.

All future professors studied and begun their academic careers in the postwar period. Most of the interviewees come from noble, intellectual families, followed by military, doctors', and teaching families and just a few belonged to people from the working classes. Among future professors, we can find individuals from impoverished teachers' homes, frequently forced by their families' economic situation or wartime events to work at a young age, as well as those raised in manors or in professorial homes filled with books. The feature that unites the poor houses of teachers or clerks and those of judges and professors is not that they possess economic capital, however, but rather cultural capital. My objective was to track the social space of to-be professors' families by defining their economic and cultural capitals. Only a few belonged to people from the rural or urban working classes, or, as it was termed at the time, of worker or peasant origin. In all cases, their education at the secondary level took place in the post-war period, and was therefore free, for many families 
significant. Only in a few cases was there no direct reference to the interviewees' origin that could also not be determined on the basis of the contextual information provided.

Bourdieu calls intellectuals "cultural capitalists," endowed with not economic, but symbolic and social capital (Swartz 2012, p. 232). Most of the professors whose biographies I compiled were also "cultural capitalists." Despite their sizeable economic diversity, especially on account of the turbulence of war (loss or death of family members, resettlements, forced work, time spent in a camp, etc.), the cultural capital not only remained resistant to these changes, but often also protected many families from economic demotion. Most importantly, though, it gave them the opportunity to choose and awareness of an open educational path - the answers that young people asked were: where (with whom) to go for education, and possibly how to pay for it, but not whether to do so at all.

In their structure, themes selection, and presentation, the academic biographies illustrate the rules of the academic field and the criteria for occupying a position within it. By tracking the construction of biographical stories, we therefore see the path of the academic biography. The collected biographical materials have a specific and constant structure. The model of academic biography reconstructed on this basis is ordered according to a predictable schema:

1) Family home - stage of reconstruction of the first inspirations, recognition of the predispositions that would be decisive and prepare the individual for an academic career, revealing the continuity, rather than chance nature, of the future career. At the same time, they reveal the work of cultural capital and the importance of factors of class in the educational paths of future professors. The descriptions of the family home usually refer to the presence of books, the beginnings of the passion for learning and interest in the world. The homes of teachers, doctors, lawyers, and nobility guarantee security and the possibility of education, an effect that is amplified in the case of professorial homes - an upbringing "in the shadow of the department" at a parent's university was said to have an inevitable impact on children's future. Choosing an academic career is presented as almost natural, as one of the authors stresses:

Fundamentally important to me was my fortunate birth as a child of an eminent scholar [...] and a teacher of languages [...] Owing to my parents' high education and profession as teachers, I was naturally a privileged child. (JK_11, p. 19). ${ }^{3}$

Much attention was devoted to children's development in a planned and deliberate way: reading together, good schools, sometimes a governess, music lessons, organisation of free time, i.e., reproduction mechanisms lasting for generations. Reference to historical context of the socialist university is rarely mentioned. A to-be-student's father calls a professor he knows to find out whether the atmosphere in the young man's

\footnotetext{
${ }^{3}$ For the few citations of narratives from the Academic Łódź project, the abbreviation "LAordinal number" is used, and for autobiographies from My Path to Academia series, "initials_year of publication."
} 
chosen area of studies might be politically improper (it is not-pre-WWII professors work there, all "the right sort" $)$. In another case, when the reviewer of a doctorate is unable to come soon enough, he is brought to Łódź by his friend, who is also the candidate's uncle-with the promise of lunch and reimbursements of all costs by her father; as a result, they succeed in holding the defence sooner (NW_06, p. 176). All these stories are described in the autobiographies as a natural element of the educational path.

2) University studies were the obvious continuation of education after secondary school-middle school (gimnazjum) and high school (liceum) - the choice of degree is an important moment of occupying a position in the field and formation of the academic habitus. The studies usually finish with employment at the university; generally, with a supervisor who has already played an important role in the future scholar's life. We can often find an overview of the eminences whom the young novice encountered at lectures or even in the university corridors. This is noted discreetly, for example, by saying "one can find the biographies of these professors in every encyclopaedia!" (ML_11, p. 92). Among the people whose studies fell in the period before and during the reform, there were several references to the interwar university and its difficult, demanding format, or, among those who started their degrees in the reformed system, to the high quality of studies, despite the new rules. As one narrator who commenced university in 1945 recalls:

What I perceived to be the main feature of that university system was the student's ability to control his path. The quota of hours that we were obliged to prove in our record books when continuing in the next academic year was ten hours per week. The departments of the Institute in charge of the subject offered specific courses from which the student had to choose-to be honest - somewhat as he saw fit. This concerned specifying what had to be done - and how many papers one needed to account for participation in one's chosen classes. A little chaos was formed in our student heads - caused by the difficulties with answering the question: how was one to set about this study lark? (PM_96, pp. 259-261)

The post-war reforms and increased access to learning from the formal angle were at odds with the pre-WWII study model recognised by the academic field-the system as a whole was working to weaken the university democratisation process (Webb et al. 2002, p. 128). One narrator, who studied in Lvov in the 1930s, notes that many students could not cope with the large choice of subjects, and put off taking exams, whose accumulation prevented them from completing their degree. The narrator herself, despite being very

\footnotetext{
${ }^{4}$ Opinions in the field meant a great deal, and constituted an internal ranking list, regardless of the official data or lists of achievements.
} 
well prepared at earlier stages of education and supported by her landowning family, struggled to prepare for classes.

The figure of the supervisor also legitimises the position or aspirations thereto, in the field, while the status of the institution where one studied and the broad conception of the academic community play a similar role. Like one's fellow students and the supervisor, the wider scientific community reveals the transmission of the desired values of the academic field. The universitas is meant to inspire and support, to subject the ideas of individual researchers to debate, and in a synergic endeavour build the progress of knowledge.

3) Academia - the rules of the academic field here act with full force, ordering the academic biography in each of the stories into recognisable markers of position. These are the academic degrees obtained, organisational functions held, stipends and trips (especially abroad), networks and collaboration, publications, conferences, awards, alumni, and tributes paid upon retirement. Sometimes a decision to work on a dissertation is synonymous with choosing the future academic career. It is usually also preceded by another important rite of passage - anointment by the supervisor or another important professor. Obviously, the narrator was not chosen by chance or without due consideration as in the fragment:

I was walking with him [his son] to the doctor, to the clinic (...) Wooden stairs, and I hear behind me a shuffling on the stairs, a patter on the stairs, and heavy breathing. The professor was a rather corpulent older gentleman. He'd seen me walking with my child, chased after me, caught up with me, and on those stairs of the clinic he said, "Dear fellow, dear fellow, I just received tenure, would you be interested in a position with me?" [laughs] (LA09)

Also, the socialist university was supposed to get rid of the "craft model," the supervisor-student relationship. This "certain feudalism of relations," at odds with the ideas of teamwork and the university-factory with set rungs of a career and criteria for promotion of a young academic. Yet the importance of interpersonal relations, criteria not based on merit such as mutual affections and antipathies, and anointing heirs, sustained the traditional system of relations. University posts, though awarded by a work order, were in fact subject to an intrinsic internal regulation-only one narrator remembers receiving a referral to work at the university at the beginning of their academic career, with all others being chosen and anointed by their professors, who applied for a position in their departments or were able to hand out posts quite readily.

Despite biographical events like this, the academic career is timeless. Historical events or the political context are presented as interventions from outside the field, distractors from the world of academia. The education reform in late 1940s, Stalinization, the Polish Thaw, 1968, and student strikes are all mentioned relatively rarely. Also treated episodically and briefly are censorship, the secret service, or problems with travel. They figure mostly in anecdotes, as outside interventions in the academic field. Yet the criteria of advancement in the field 
were tightly regulated by the central authorities, debates raged on, and a succession of reforms was implemented. ${ }^{5}$ Nevertheless, little is reflected on about these issues. Academia is presented as a timeless and apolitical entity. The absence of politics is doubtless mainly related to the representation of the model of the academic biography as a conflict-free process without any tensions or arguments. As John Connelly notes in his numerous publications (Connelly 1999, 2000; Connelly and Grüttner 2005), Polish academia was incorporated into the Party structures to a lesser degree than was the case in East Germany and Czechoslovakia. Communist scholars were "ghettoised" in departments of MarxismLeninism and had little influence on the academic community (Connelly 2005, p. 198). In the most frenzied period of Stalinism around 1953, only $9 \%$ of students ${ }^{6}$ and $10.7 \%$ of professors belonged to the Party; in 1958 the figure for students was just 2.5\%, but the percentage of Party members among academic faculty had risen to $11.4 \%$ (Fijałkowska 1985 , p. 174). Hostility to both communism and Russia was rife among most of the academic community. The Party initially opted for a conciliatory policy, and the majority of the pre-WWII faculty who survived the war and came back to Poland returned to high positions, regardless of their political views. Loyalty to the scientific community was dominant, not to the Party. The appointed rectors tended to be faithful to their universities, playing the role of mediators between political pressures and the independence-seeking academic community. In the Soviet Union and GDR, the academic community found itself in a far worse position(Connelly 2000), and also in comparison with Czechoslovakia the ideologization of academia was less pronounced (Jirásek and Malkiewicz 2005).

Additionally, with the ideal of pure knowledge comes the need to devote oneself absolutely to the academic field - a recurrent motif in many biographies is dedication to academic work, regardless of the economic and political benefits and even personal comfort. The choice of the academic path is emphasised to varying degrees, in spite of its economic unattractiveness: "For the sake of being true to the realities of those times, I would like to inform that to take up the position as assistant with a salary of 2600 zloty, I left a job as an official in nationalised industry, where my pay had been four times higher" (PW_96, p. 268). There was even a proposal that academics' salaries should be low in order to discourage people engaging in scholarship for profit from joining the profession, thus keeping it the preserve of the enthusiasts who were true scientists (LA20). According to biographies, academia is not merely work, an area of professional activity, but also one of vocation and sacrifice. This is possible because of the unique status it receives, at the level of ethical values, its exceptional role in civilisation and the autotelic value of cognition itself. The status of academia itself is therefore woven into para-sacral values and the university presented as a "temple of learning," and consequently professors bear the additional load of demands of a moral nature. Considering an influence of the official Marxism or Stalinism-Leninism, some professors choose a form of mimicry. As one of them explains: "for it was becoming

\footnotetext{
5 The 1948 reform regulated also the period required for writing the various degree dissertations and the rules of academic faculty selection, transferred to the ministry the right to confer the titles of professor and associate professor, briefly introduced the title of candidate of science, and connected titles to academic degrees. From 1954, some of these moves were abandoned, and the next reform, in 1958, again changed the regulations in the field - the degrees of doctor and associate professor were awarded by the Faculty Board, professor by the State Board, appointments as tenured associate professor were made by the minister and the position of senior lecturer was also introduced. In the narratives and biographies, this topic is barely present.

${ }^{6}$ Although from 1949 between 65 and 80\% were members of the Union of Polish Youth (Szczepański 1959)
} 
clear that, by making skilful use of historical and dialectic materialism and adroitly choosing quotations from the classics, one can defend a number of just causes" (KJ_00, pp. 23-24). The "pure knowledge" notion stands in clear contrast to the role and values of the socialist university, proposed by the government reform.

The post-WWII change that the socialist university was supposed to bring was the socialisation of academia, making it a field subordinated to both society — and thus also the Party that governed it - and the economy. This was supposed to mark a move away from academia as the domain of scholars, construed almost as their private property. The biographies contain several warnings against external factors interfering in scholars' research activity. The best way for scholarship to develop is unfettered by any limitations - either economic or political demands. The socialist university model was supposed to change the very manner of studying and acquiring knowledge. Yet the future professors remember the period of reform as a negative reference point. These are references to the happiness that came from starting one's degree before the reform, or passages that almost defend their authors' own competences, stating that despite studying in the reformed system, the studies were of a high level. The biographies depict the academic field as an autonomous circulation, generating defence mechanisms against any outside interference.

4) Completion — usually meaning retirement. A time of summing up achievements, which reveals an academic's status through official farewells, jubilee conferences and publications, students continuing the professor's research interests, awards, and distinctions. Further scientific activity is also emphasised. When reconstructing their careers, professors never leave their roles. Their stories tend to be grandiloquent rather than small-minded, engaged, not distanced, and serious, not jocular (apart from the numerous anecdotes that often appear). The belief in the inseparability of one's own life and work cannot remain closed inside the professional sphere, but permeates the entire life and experience. The whole of the academic field seems to be an area of certain superior principles and valuessubstantive, cultural, and even ethical. This superiority reinforces the cultural arbitrary as universal. Rather bombastic expressions about the scholar's mission, work, or superior values can be found in many autobiographies, such as this female professor's somewhat prophetic summary:

"From this difficult, laborious, and risky path I took away two, not so much benefits, as observations. The first is that the scientific path is littered with many thorns, and requires "Benedictine" toils and sacrifices. The second is that those embarking on this path will have no peace and will not abandon their muse. For they know that they are in its control. Yet woe to those who for opportunistic purposes disregarded its instructions. They'd have been better off staying silent forever." (LZ_96, p. 204)

There cannot be many better guarantees of one's own privileges and maintaining the hegemony of a given group in society. It is a distinction that ensures reproduction of the cultural arbitrary of the dominant classes. One female narrator concludes that what is most precious in scholars is their ability to distinguish true values and remain true to 
them-yet they are the ones who are responsible for the criterion of this truth. After all, there are no concrete designates behind universal expressions like "proper" and "decent."

In professors' everyday gestures, from giving praise and teaching seminars to ceremonies and conferences, self-reproduction of the system takes place, under the spell of the practice repeated by their students. In this context, an emblem of transformation might be the abandoning of the custom of wearing professorial robes at the University of Łódź, intended for realisation of the model of a socialist university. Yet gowns were reintroduced as early as the 1950s. Professors and students work hand in hand to produce the institution of which professors are already a product. Selection of students follows an expectation of inherited dispositions for academic work, and thus of those best suited to the demands of the field (but not the apparent scholastic requirements faced by most aspiring students from lower-class backgrounds). Without adopting the whole of the academic habitus, it is hard to attain a position in its core. With this in mind, I discuss in the next section interesting differences occurring in peasant biographies.

\section{Untrue visions}

In the Polish People's Republic, the democratisation of education took place 20 years earlier than in France and with extremely large-scale attempts to change the social structure. Examining the few biographies of les miraculés - the wonderboys - I wish to ask about the existence of a rural or urban working-class academic career that would be different from the elite model presented earlier. "The Inheritors" begins with a quotation from Margaret Mead regarding visions among the Omaha Indians. The visions, whose authenticity was judged by the community, were theoretically an egalitarian means for the elite families to emerge. All the young men in the society would describe their dreams, which a local council assessed to gauge their authenticity. Yet the "true" visions were in fact confined to the children of the appropriate families, who already belonged to the clan elite. In a sense, peasant and worker biographies in the academic field are deviant career paths, not fitting the system of social reproduction-their dreams were forcefully recognized by academia. The deviation concerns the incongruence of the position in the field to previous dispositions. Yet, examples of such deviant paths would be both impoverished noblemen of the interwar period seeking intellectual positions, and the advance of proletarian daughters to teaching roles. Their starting position and the educational path that this determined assumed a different course of the biography.

Bourdieu's analyses of higher education are very critical of its institutions, and often full of bitter observations. The prefaces and introductions to Bourdieu's works almost always mention his social background as a factor explaining his later interests. Deborah Reed-Danahay underlines the similarity between his biography-Bourdieu was the son of a provincial postal worker; and the life stories of socially advanced intellectuals. Those would be the Breton writer Pierre-Jakez Hélias or the American writer Richard Rodriguez, a folklorist and the son of rural immigrants (who focused on ethnic distinctiveness, as opposed to Bourdieu's emphasis on the class distinction), or the 
aforementioned Richard Hoggart, whose interests in the working class are closely enmeshed in his own biography (Reed-Danahay 2005, p. 32). A Polish sociologist, Antonina Kłoskowska uses a similar analogy in the introduction to the Polish edition of Reproduction in Education, Society and Culture (Bourdieu and Passeron 1990), comparing Bourdieu's biography with that of Józef Chałasiński. The Polish professor studied under Florian Znaniecki in the interwar Poznań and was a second rector of University of Łodź, where our les miraculés were studying in the 1940s and 1950s. Bourdieu's argument (like that of Hoggart) is a similar one to that made 40 years previously by this Polish agrarian thinker. While analysing peasant youth in his book The Young Generation of Peasants (Chałasiński 1938), Chałasiński identified the "pupil model" and the "shepherd model" who were disinherited from their own cultural contexts by social advancement. This leaves one with three potential paths: (1) submitting to the system and abandoning attempts to overcome the deprivation caused by advancement; (2) despite submitting, attempting to achieve individual success within the system; (3) rejecting-to use Bourdieu's termsthe arbitrary of legitimate culture. This last option involves attempting to oppose the dominant culture and the system of the institution, of its own values system. Only this path leads to true emancipation. Bourdieu, meanwhile, seems to see an emancipatory potential only in replacing the former culture with a new one with new rules of the arbitrary and its own set of legitimate valuesexactly as the construction of the socialist university tried to do. However, of the biographies collected for the research, only a few were of people of modest social background - those who were supposed to be model socialist professors and introduce a new cultural hegemony and new rules.

An exceptional leap characterised transgression of the pre-war but also post-war peasant biographical path - a university professor from the working classes was a rarity. This extraordinary mobility into faculty position meant an adaptation to traditional academic habitus despite the supposed socialist one. Supposedly perfect "material" for future socialist professors not only struggled to become a faculty at all, but failed - or never really tried - to became a socialist one. According to the collected biographical materials, there were only a few differences between the academic careers of people of elitist origins and those from the working classes. The distinguishing elements of the biographies were:

1) Family home-If we take seriously the assumption that what differentiates the populations is not class, but the history of the educational career (Wacquant 1989), therefore the initial part of the biographical path differentiates society most strongly. In the previous section, I dealt in depth with the family home as an important reference point in the academic biography. One professor, himself from an intellectual home, divided his fellow students after the war into "first-class passengers" who had attended good schools with good teachers and "third-class passengers," who:

[...] were and are those who brought and today bring nothing from home, apart from the principles of honesty, and who did not experience good teaching at 
school. I always treated those from the third category with the greatest respect, as they obtained positive results through their own work. (SJ_96, p. 298)

However, what is describes in peasant academic biographies is low cultural capital and a significant role of external factors such as the teacher, organisation, or influence of the political field. In the case of elite biographies, the reference to the domestic context was a compulsory element of the narrative structure. The stories of people of working-class/peasant origin often omit the childhood or mention it only in passing, beginning their narrative only in the post-war period and the start of high school, taking the school-leaving exams, or even only once going to university. Among the stories about "getaways" or "our manors," "devoted servants," painters and professors for dinner or trips to museums and bedtime stories, the narrators from modest backgrounds tend to limit the passages discussing their family homes to a few sentences, very modestly referring to their early struggles.

Language is one of the first obstacles or first transparent facilitators on the educational path. For children from homes with high social capital, using correct pronunciation and syntax as well as a rich vocabulary are an obvious, although often invisible privilege. For peasant and working-class children, dialect, accent, and grammatical errors are one of the earliest perceptible obstacles that distance them from the academic biographical path. Linguistic deficits are significant even at the earliest thresholds of school selection. In this somewhat deterministic perspective, an educational failure is closely related to linguistic competences. Firstly, it conditions experiencing the world through the linguistic code one uses. Secondly, dialect does not belong to the dominant culture and is depreciated-working-class children must lose it in order to function in the school system. In addition, Bourdieu shows that academic teachers' tendency to assume wrongly that linguistic patterns are manifestations of intelligence results from their "class ethnocentrism" (Bourdieu et al. 1996, p. 8). This issue is hardly mentioned by the interviewees, with one exception: "Quite soon, probably thanks to appropriate reading, teachers and the whole community, I lost all traces of my dialect" (RJ_00, p. 144). Another consequence is the hyper-correctness characteristic of those who have undergone social advancements (Grenfell 2004, p. 29). Often during the interviews, it was people from intellectual homes who would make language errors, while the few interlocutors from families with lower social capital were greater linguistic purists. One of them, from a railwayman's family, not only paid close attention to correct construction of his own oral statements, later reediting the entire interview, but also corrected the slightest mistake made by other people, including me, the interviewer.

2) Breaking through-The most important moment is the breaking of the biographical path-entering a deviant career from a perspective of one's class origin. This often entails father's promotion to the position of skilled

\footnotetext{
${ }^{7}$ Original quotations from the autobiographies.
} 
worker in a factory or state official (railwaymen or postal worker), or the fierce parents' insistence on providing their children with a better life than their own through educational advancement. For most people, the primary school period comes in the inter-war time or during the war. Although this stage is a predictable element of the biography, especially after the introduction of compulsory schooling in 1918, every subsequent level of education is problematic and not to be taken for granted. Financial difficulties associated with transport or boarding (or, more commonly, cheaper private lodging) are as difficult to overcome as the initial lack of knowledge. Especially in the pre-war stage of education, nothing is known or obvious; no tracks are marked for a family to follow. Post-war education research showed that during the war, underground education on the one hand stepped up selection mechanisms and consolidated elitism, especially in the case of higher education, and on the other improved access to education for young people from rural areas. Many teachers and lecturers spent the war in the countryside, teaching and giving private instruction to the local youth. In post-war educational paths, the higher educational levels become more obvious because of free education, numerous scholarship programmes, developed infrastructure, such as boarding schools, halls of residence, the opening of thousands of schools, but also changes in public discourse. The choice of a pedagogical high school was seen as a relatively safe path, guaranteeing a career after graduation, and not closing the path to higher education.

3) The need to avoid privilege - The post-war system created paths of advancement for the new intelligentsia only to a certain rung of the social ladder. To climb higher, right up to the most prestigious positions, it was necessary to break from the socialist plan for the new intelligentsia's biographical path-by avoiding a work order or not accepting a scholarship that would need to be paid off later by working. Interestingly, advancement in the Polish People's Republic, even for people of the "right" origin, was quite strictly controlled and not easy. Young people were subject to work orders, university referrals, and other regulating mechanisms of social advancement. As one interviewee recalls:

One person in a class, sometimes two, could be excused a work order if they were going to university, but they had to distinguish themselves in some way at school. And I was fortunate enough to be excused the work order, but my 18 year-old friends, girls, boys were referred to rural schools, and here - in central Poland and the western territories. Low wages, very tough working conditions. But what is really worth mentioning is that they were not afraid of that hardship, they did not shirk it. (LA09)

On top of this came even more curious situations, when the mechanisms meant to facilitate education and guarantee work after its completion brought the opposite effect at the level of individual practices (Boudon 1982). Similarly, another professor had to avoid the award of a scholarship in order to go to university at all: 
After completing middle school I completed high school, and they tried to give me a work order at a school, because as a pupil, despite all the difficulties and arrears that there were, I had made up for a lot of things and distinguished myself appropriately. I belonged to a sort of class elite, of the best pupils. I decided to go to university. Since it was a pedagogical high school, there was a lack of teachers after the war, so they tried to rope me in, the money would be useful, and I was awarded a scholarship by the Department and they tried to force me to accept it. But a couple of months before the leaving exams, I refused to accept the scholarship, expecting that if I took the money, there'd be a pretext, I'd have to work it off. And as a result I got into university. (LA01)

The theoretically better and safer conditions of a career guaranteed by the state represented an obstacle in continuing one's education, which was so highly soughtafter. The numerous obstacles on the career path were not only the material situation or available infrastructure, but especially making bad decisions, wasting time gaining skills that were useless from the perspective of university education, and choices enforced by the material situation or need for social security.

The narrators in question chose history, biology, and geography as their subjects. These disciplines are popular among students from the working classes, and especially those with rural origins (Bourdieu and Passeron 1990). An interest in biology and geography is related to close contact with nature, as one of the interviewees recalls: "I spent a lot of time in my youth at the river, in the forest. So I knew nature, understood it, but didn't have names for it" (LA09). History, meanwhile, was of interest because of its relatively high accessibility through oral family histories and popular literature available in local libraries.

4) Craft - the next important element is hard work and scholastic skill. The work ethos is present in all the professors' narratives, yet this is an ethos associated with the intellectual mission, a passion for discovery, but not with work in the sense of craft, which emerge in the narratives of people from the working classes. As one of the narrators says, "I treated my studies as work-you get nothing without working for it, so I studied." He was a hard-working and conscientious student, who also illustrates his attitude to his studies with a story about an award:

[...] as was the case then, there were a lot of exams, I was surprised in the autumn, because I got into university in ' 49 , so in autumn ' 50 my colleagues informed me that I was on the list, I'd received a prize for passing the exam, so I couldn't really understand at all how you could give an award for something that was my obligation. (LA01)

Another interviewee even uses factory terminology, explaining that:

In academia you never feel your shift is over, as there's always something you have to do. Even when you come home from work, you get away at any time to sit at the desk or table and read, write, make notes, do something. (LA09) 
The craftsman's work ethos involves satisfaction at getting the work done. As pupils and students, future professors of modest origin climb the educational ladder with great determination. Each successive choice, like attending pedagogical high school, taking the risk of circumventing the work order or turning down a stipend in order to go to university, are turning points away from the socially expected career.

5) Significant non-academic activity — apart from their craftsman's work ethos, the interviewees are often activist types - often like their parents, whose social engagement and desire for education allowed them to change their children's educational path. All the interviewees and authors of autobiographies certainly benefited from the transformations and were members of the Party, or the ZMP during their student days. In this period, they benefited from scholarships, halls of residence, and canteens and the reconstruction of the social imaginary valued them as citizens and showed them new possibilities. One interviewee relates his wonder at the chances that living in a city brings, and how he grabbed the city's cultural opportunities with both hands, as well as getting involved in the Polish Youth Union and participating in building halls of residence, others are Party members, community activists, or those who engage in additional educational initiatives.

One interviewee underscores the duty placed upon him as a professor educated with public money: "I grew up in the atmosphere that you make use of the benevolence of society, and need to give something back to society for all that" (LA01). Another recalls "my parents also dreamt of educating me - as one said in the countryside - 'as a gentleman'” (RJ_00, p. 139). After studying at clandestine classes found by his father, he became involved in the agrarian youth organisation. This was a formative event, as he encountered a completely different milieu, including better-educated activists. They exchanged readings, he had access to a library, and, as he put it himself, "As the first high-school graduate in the family, I sat on a magic carpet that carried me to the Medicine Faculty." Aware of the political situation in the context of his background, he writes:

I wish to express my deep-rooted conviction, coming from my family and community, and not the result of indoctrination, that I consider myself a beneficiary of the social transformations that took place in our country after liberation and allowed me and others like me access to knowledge. (Ibid., p. 146)

The working class biographies are torn between elements of the peasant habitus and the rules of the academic field. The often described rupture in the biography related to advancement takes on another dimension in the context of socialist modernisation. Social engagement and the significance attached to teaching might be associated with the sense of owing a debt to the class of origin. However, they usually completely lose contact with the previous community. At the same time, they feel grateful to the system or society as a whole for offering them the chance to study. This would be a widely described sense of guilt towards the community that they left, something present in people who have advanced, including Bourdieu himself, and probably Chałasiński too.

An interesting context is provided by research on academic teachers carried out in the 1980s (Najduchowska and Wnuk-Lipińska 1990). This showed that various characteristics of individuals hardly correlate at all — type of university, community, and origin - and the 
remaining correlations do not form any pattern. Apart from the below exception, if someone's father was educated to a level lower than the average in the community, there was a positive correlation with membership of the Polish United Workers' Party and Polish Youth Union and a negative correlation with belonging to independent organisations.

6) Positive attitude towards the Polish People's Republic - The narrators tend to express their gratitude towards the Polish People's Republic, some more explicitly than others. At many points we can also observe a strong affection for and idealisation of this period. A sense of gratitude for the political changes of the post-war period, disappointment at the transition time and a critical view of the post-1989 period, as well as a negative contemporary evaluation of the communist era, are common.

An important element in their stories in this context is their poverty as students contrasted with their later stability. Undergraduate days and the first years of work as an assistant are a time of lack of money and privation. References to scarcities are balanced by the later successes or, rather, the scale of successes is determined in regard to the wretched starting point. Interviewees particularly valued receiving a flat, owing a car, but also simple matters like having milk delivered to their door by the "Społem" Consumers' Cooperative (KT_00, p. 75).

In this context, the verdict on the transition of 1989 is decidedly critical. Apart from good funding of scholarship, democratisation of higher education - no longer from the individuals' own perspective - is also presented as a key post-war accomplishment: "I share the joy (...) that after 1945, rural youth swarmed to middle schools (...) Today I regret that this swarm has come to a halt" (KT_00, p. 66). Interviewees from the intelligentsia, though both left-leaning Party members, also comment on the scale and significance of this phenomenon:

Sometimes when I listen to the recollections of young people, reflection of young journalists or young politicians on the darkness that hung over the land in communist times, I feel a little uneasy, and I'm extremely critical towards all historical materials. I must say that I'm a huge sceptic when it comes to so-called historical studies, because I look at what gets written about the People's Republic at the moment and I'm able to judge what happened and compare it to the opinions that come out now on the subject. I certainly didn't feel any... perhaps I'm applying another comparative scale here. A young man [himself], who, from the level of school libraries and everything that was in bookshops, immediately entered a world of indeed very intellectually significant people. (LA02)

At the same time, elitist biographies far more frequent describe such issues as obstacles to travel, excessive bureaucracy, difficulties with getting hold of publications from the West, or long waits for reagents ordered in exemplary fashion.

The differences mentioned are only points in the whole biography, which are essentially no different from the others - they too are ordered by academic degrees and other markers of the field. Despite the huge differences at the beginning of the educational path, the widely varying conditions in the family home and the weak cultural and social capital, the structure 
of peasant biographies follows almost the same track as the intellectual ones. Although the post-war social imaginary meant different possibilities, new career paths, and the formation of educational desires, the change was incomplete. To put it in Bourdieu's terms, the habitus of the working classes still did not meet the requirements of the academic field - this remained unchanged, and the hysteresis effect continued to sustain the pre-war values. In the retired professors' narratives, the differences from the intellectual habitus are no longer discernible, but they are revealed in the margins and the form of the story (language, narrative structure). The academic doxa encompasses all professors.

\section{Opposing vectors of the hysteresis}

The one-third of Poles experienced upward mobility in post-WWII period, mainly millions of peasants who experienced the remarkable leap from the "squalid hut" to higher education and who in later years would fill factory offices, hospitals, courts, and schools. To a much lesser extent, they reached university departments. Those who managed to do so entered an alien milieu to them. In the academic field, it was still rather more an interwar than a socialist university model that was in place, still the prewar academic habitus that was valued and the structural changes of the political field were viewed as hostile outside interventions. Young novices arrived at university with a very hazy idea of what studying meant and what a university and knowledge were. They were beneficiaries of the transformations, and believed in the system and the opportunities it gave them. They were ideal material for a new, socialist academic faculty. So why is this not what they became? Why are their biographies so similar to others-both at the structural level and that of the presented rules of the field? Why did the model of traditional academia and its values compromised in the public discourse become their model?

Let us return to the opposing vectors of the hysteresis effect outlined earlier. The hysteresis effect works on two levels and with opposite vectors. On the one hand, the academic field is meant to adapt to political changes, which causes resistance from the pre-war academic habitus, striving to reconstruct the traditional university modelled on the liberal university. As we saw, the changes at this level exclude many pre-war professors from institutional life, enable careers supported by political capital, and finally open huge possibilities for the urban and rural working classes as the new intelligentsia. Hysteresis slows these changes down - the inertia of the habitus delays change. On the other hand, the hysteresis effect also works within the academic field, with its vector pointing in the opposite direction. The doxa of the academic field remains unchanged. The young university novices, wishing to take their place in it, are also subjected to the hysteresis effect, and have to adapt to the habitus of pre-war academia. On the one hand, the post-war social system provided new paths of social mobility. It offered a change in the structures of the academic field through the pressure of the political field, and unveiled new possibilities to the actors, especially those who were previously excluded, who were most affected by the selection mechanisms. On the other hand, after embarking on the academic path, the beneficiaries of the socialist transformations adopted the traditional habitus almost entirely. According to analysed material, the governmental universities' reform did not have an impact on the internal rules of academia and the traditional university model. 
The narrative of the captive university and shackled academia represented in some of the intellectual biographies and in the historical discourse on the Polish People's Republic concealed the highly conservative nature of the academic field. In fact, it had strong immune characteristics. To a large degree, the academic field preserved its autonomy and permanent corpus of values and criteria enabling a position to be taken within it. In this way, the hysteresis effect is played out not between the political field and academic's habitus, but between the permanence of the academic field and the habitus of the working classes. As Bourdieu showed, the academic habitus always demands some work from those entering the academic field, yet its scope varies depending on the distance from the field itself - which is largest and most difficult to cover for the working classes. The academic field remained autonomous enough that the habitus of those entering it "illicitly" underwent a stronger hysteresis effect. This still happened in spite of the radical attempts at rebuilding the entire education system.

In 1960s France, education was popularised, but not democratised. The proportions of the social makeup of students remained the same. One might expect that the influx of a larger number of low-class students would mean that academic instruction would adapt to the level of sophistication, especially as many teachers came from advancement too and had to assimilate in the academic habitus from the beginning. Yet this did not happen. Teachers from advancement were all the more zealous in defending the traditional values and esoteric language of academia, in order to prove their authenticity and legitimacy in the field. They recognised the outward signs of mastering knowledge (like linguistic correctness), engraving titles and subtle status symbols, and perceived all attempts at change as a threat (Bourdieu and Passeron 1990, p. 95). Information and understanding are in the domain of the inheritors, whereas les miraculés sense the degree devaluation that comes with the massification of education owing to the lack of social capital. Yet they do not sense this, and they remain proud of their accomplishments, like the groups in which they circulatetogether, they mask the effect of devaluation. The new generations entering the system have expectations formed on the basis of the previous experiences, when degrees did not devalue. Passeron and Bourdieu summarize the situation by saying that the working class, after long resistance of the ideology of education as liberation, finally succumbed to it and entered the system, only to then (despite awakening of its ambitions) obtain second-rate positions.

It was a similar case with post-war academia in the Polish People's Republic, where reform of universities happened 20 years earlier under different political conditions: the prewar university, haunted by the vision of itself as a liberal university, defended itself from the "invasion of the barbarians." The changes introduced by the building of the socialist university were only a façade. At the level of the whole field, the education system changed little. The emphasis placed on educating young people (born in the 1920s and 1930s) as a new intelligentsia did not reach the academic field. For example, one of the authors with origins in the intelligentsia mentions that during the Stalinist period, as a young assistant, she was dismissed from her job. Yet this did not harm her academic career much, since when she wrote her memoirs she was a professor of the same institution. According to Connelly, of eleven assistants dismissed as a result of the 1948 reform, nine of them continued their academic careers. Furthermore, in 1951-54, the titles of professor and associate professor were awarded to 302 people, only 41 of whom were Party members (Connelly 1999, p. 198). Academia defended itself from top-down changes. Among academic faculty studied in the 1980 s, of 2000 academic teachers, $68 \%$ teachers at universities were from an intellectual background (59\% at polytechnics), while among students surveyed in 1979, the majority of 
those wishing to continue an academic career were from intellectual homes (Najduchowska and Wnuk-Lipińska 1990).

Contrary to popular opinion, it was not only political pressures that determined the position in university issues in the Soviet Block, but also the positions held by specific actors in the academic field. The anticipated biographical path for people of peasant origins was broken, but the new one demanded sacrifice and adoption of a new habitus. The new intelligence can take on the model of the socialist habitus - it will then take the positions of specialists, technical intelligentsia, and no doubt also academic faculty at technical and agricultural colleges. To occupy a position at the heights of the academic field, however, among adherents of the elite traditional academia pursuing pure knowledge, they must adapt to the rules in place there. Narratives about captive or shackled academia lose sight of the key dimension of the change - the symbolic violence of the political field was not as strong as that within the academic field.

To simplify Bourdieu's perspective somewhat, the function of pedagogical conservatism is for a small group of dominant classes to defend their position. They protect their positions from the invasion of barbarians, their weapon in this fight being the defence of the social order and higher culture (cultural arbitrary hidden as universal). Just as the intelligentsia in the Soviet Union aspired to the values of the dethroned bourgeoisie, sending their children for piano lessons and piling up heavy cupboards and cabinets in their canteens (Fitzpatrick 2002), the young scholars entering the world of academia also desired the attributes of power and prestige of a world that was supposed to have elapsed.

The conflict between intellectuals and the working class appears at many levels: aesthetic tastes, life orientations, attitudes to faith, etc. (Swartz 2012, pp. 239-244). In the case of the narrative about "captive university," the political dimension of change obscured all the others. This is a concentration on institutions and their policies that typifies not only the totalitarian paradigm, but conventional history in general. The hysteresis effect worked on two levels, but only one was prominent. Contemporary discourse about the Polish People's Republic was appropriated by the intelligentsia, for which it was a regression. Their hegemonic position in cultural production was threatened by the socialist modernisation project. This might help to explain the domination of the narrative of darkness, captivity, or homo sovieticus. From perspectives that viewed Poland's post-war history as a modernisation project, emancipation and empowerment of thousands of people were easily marginalised as the sentimental visions of Party people, the effect of unconscious indoctrination, or seduction of the young with totalitarian propaganda. Indeed, the project failed. Bourdieu tries to show, in The State Nobility for instance, that the presence of les miraculés in higher education does not prove the democratisation of the system, but rather that their uniqueness reveals the reproduction mechanisms from the earliest school years. In the case of communist Poland and peasant children advancing to become university professors, this meant inclusion in the huge modernising machinery of post-war reconstruction and Stalinism. It was not possible to change the social system, including the rules of reproduction, without changing the whole education system - which was why there was an upturn in numbers of students from urban and rural working-class backgrounds, but not a permanent one. The controlled mobility of outside individuals essentially underpinned the social structure.

Acknowledgments The research for this article was realized at University of Lodz, Poland, financed by the Polish National Science Center, research grant Preludium 2 contracted as UMO-2011/03/N/HS6/01948. 
Trajectory of academic biography

\begin{tabular}{|l|}
\hline Home and childhood \\
family origins \\
first inspirations \\
first important other \\
(parent/teacher) \\
predispositions \\
\hline
\end{tabular}

Studies
conscious and free
choice of subject
occupying place in the
field
followed by
employment

Differences in peasant biographies in academia

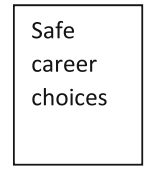

Avoiding
privilege in
Polish
People's
Republic

\begin{tabular}{l} 
Academia \\
successive academic \\
degrees \\
networking \\
trips and stipends \\
external opinions \\
teaching \\
\hline
\end{tabular}

\begin{tabular}{|l|}
\hline Completion \\
students and schools \\
prizes and awards \\
valedictions and \\
tributes \\
continued activity \\
\hline
\end{tabular}

Engagement and active participation in political life

\section{Affection for previous era \\ Criticism of transformation}

Fig. 1 Academic biography and peasant academic biography (own elaboration)

Open Access This article is distributed under the terms of the Creative Commons Attribution 4.0 International License (http://creativecommons.org/licenses/by/4.0/), which permits unrestricted use, distribution, and reproduction in any medium, provided you give appropriate credit to the original author(s) and the source, provide a link to the Creative Commons license, and indicate if changes were made.

\section{References}

Andreas, J. (2009). Rise of the red engineers: The cultural revolution and the origins of China's new class. Stanford: Stanford University Press.

Boudon, R. (1982). The unintended consequences of social action. London: Macmillan.

Bourdieu, P. (1984). Distinction: a social critique of the judgement of taste. Richard Nice, translator (1984th ed.). Cambridge: Harvard University Press.

Bourdieu, P. (1988). Homo Academicus. Stanford: Stanford University Press.

Bourdieu, P. (1989). La noblesse d'état: grandes écoles et esprit de corps. Paris: Les Editions de minuit.

Bourdieu, P. (1998a). The "soviet" variant and political capital. In Practical reason: On the theory of action (pp. 14-18). Stanford: Stanford University Press.

Bourdieu, P. (1998b). The state nobility: Elite schools in the field of power. Stanford: Stanford University Press.

Bourdieu, P. (1999). The weight of the world: Social suffering in contemporary society. Stanford: Stanford University Press.

Bourdieu, P. (2000). Pascalian meditations. Stanford: Stanford University Press.

Bourdieu, P. (2010). Outline of a theory of practice. Cambridge: Cambridge University Press.

Bourdieu, P., \& Passeron, J. C. (1979). The inheritors: French students and their relation to culture. Chicago: University of Chicago Press.

Bourdieu, P., \& Passeron, J. C. (1990). Reproduction in Education, Society and Culture. R. Nice, Translater. London: Sage.

Bourdieu, P., Passeron, J.-C., \& Martin, M. d. S. (1996). Academic discourse: Linguistic misunderstanding and professorial power. Stanford: Stanford University Press.

Bozóki, A. (Ed.). (1999). Intellectuals and politics in Central Europe. New York: Central European University Press.

Chałasiński, J. (1938). Młode pokolenie chłopów. Warszawa: Państwowy Instytut Kultury Wsi. 
Connelly, J. (1999). The foundations of diversity: Communist higher education policies in Eastern Europe 1945-1955. In K. Macrakis \& D. Hoffmann (Eds.), Science under socialism: East Germany in comparative perspective (pp. 125-139). Cambridge: Harvard University Press.

Connelly, J. (2000). Captive University: The Sovietization of east German, Czech and polish higher education (pp. 1945-1956). Chapel Hill: University of North Carolina Press.

Connelly, J. (2005). Polish universities and state socialism. In J. Connelly \& M. Grüttner (Eds.), Universities under Dictatorship (pp. 1944-1968). University Park, Pennsylvania: Penn State Press.

Connelly, J., \& Grüttner, M. (2005). Universities Under Dictatorship. University Park, PA: Penn State University Press.

Domański, H., \& Tomescu-Dubrow, I. (2008). Nierówności edukacyjne przed i po zmianie systemu. In H. Domański (Ed.), Zmiany stratyfikacji społecznej w Polsce. Warszawa.

Eyal, G., Szelényi, I., \& Townsley, E. R. (2000). Making capitalism without capitalists: Class formation and elite struggles in post-communist Central Europe. London: Verso.

Fijałkowska, B. (1985). Polityka i twórcy 1948-1959. Warszawa.

Fitzpatrick, S. (2002). Education and social mobility in the Soviet Union 1921-1934. Cambridge: Cambridge University Press.

Grenfell, M. (2004). Pierre Bourdieu: Agent Provocateur. London: A\&C Black.

GUS. (1955). Rocznik statystyczny. Warszawa: GUS.

Hardy, C. (2012). Hysteresis. In M. Grenfell (Ed.), Pierre Bourdieu: Key Concepts (pp. 126-146). Durham: Acumen Publishing.

Herczyński, R. (2008). Spętana nauka: opozycja intelektualna w Polsce 1945-1970. Warszawa: Semper.

Hübner, P. (1992). Polityka naukowa w Polsce w latach 1944-1953: geneza systemu. Wrocław: Zakład Narodowy im. Ossolińskich.

Jaczewski, B. (Ed.). (1987). Życie naukowe $w$ Polsce $w$ drugiej połowie XIX $i w$ XX wieku: organizacje $i$ instytucje. Wrocław: Zakład Narodowy im. Ossolińskich.

Jałowiecki, B. (1996). Oblicza polskich regionów. Warszawa: Uniwersytet Warszawski. http://www.euroreg. uw.edu.pl/p1/publikacje,oblicza-polskich-regionow. Accessed 20 June 2018

Jirásek, Z., \& Malkiewicz, A. (2005). Polska i Czechosłowacja w dobie stalinizmu (pp. 1948-1956). Warszawa: Studium porównawcze.

Konrád, G., \& Szelényi, I. (1979). The intellectuals on the road to class power. San Diego: Harcourt Brace Jovanovich.

Kotkin, S. (1998). 1991 and the Russian revolution: Sources, conceptual categories, analytical frameworks. Journal of Modern History, 70(2), 384 425. https://doi.org/10.1086/235073.

Maton, K. (2012). Habitus. In M. Grenfell (Ed.), Pierre Bourdieu: Key Concepts (pp. 49-65). Durham: Acumen Publishing.

McDonough, P., \& Polzer, J. (2012). Habitus, hysteresis and organizational change in the public sector. Canadian Journal of Sociology, 37(4), 357-380.

Mycielska, D. (1981). Drogi życiowe profesorów przed objęciem katedr akademickich w niepodległej Polsce. In R. Czepulis-Rastenis (Ed.), Inteligencja polska XIX i XX wieku: studia, t. 2. Warszawa.

Najduchowska, H., \& Wnuk-Lipińska, E. (1990). Nauczyciele akademiccy 1984. Warszawa.

Ollion, E. (2015, July 31). The rise of Pierre Bourdieu in US sociology. https://blog.oup.com/2015/07/pierrebourdieu-us-sociology/. Accessed 20 June 2018

Palska, H. (1994). Nowa inteligencja w Polsce Ludowej: świat przedstawień i elementy rzeczywistości. Warszawa.

Pop, L. (2018). Bourdieu in the post-communist world. In T. Medvetz \& J. J. Sallaz (Eds.), The Oxford handbook of Pierre Bourdieu (pp. 146-158). New York: Oxford University Press.

Reed-Danahay, D. (2005). Locating Bourdieu. Bloomington: Indiana University Press.

Siegel, K. (Ed.). (2002). Issues in travel writing: Empire, spectacle, and displacement. New York: Peter Lang.

Słabek, H. (2001). Wychodźstwo robotnicze: awans społeczny jednostek i zubożenie klasy? In T. Szarota (Ed.), Komunizm: ideologia, system, ludzie (pp. 313-324). Warszawa: Neriton.

Susen, S., \& Turner, B. S. (2013). The legacy of Pierre Bourdieu: Critical essays. London: Anthem Press.

Swartz, D. (2012). Culture and power: The sociology of Pierre Bourdieu. Chicago: University of Chicago Press.

Swartz, D. (n.d.). Bourdieu's Concept of Field-Sociology-Oxford Bibliographies. http://www. oxfordbibliographies.com/view/document/obo-9780199756384/obo-9780199756384-0164.xml. Accessed 18 Feb 2019

Świda-Ziemba, H. (2003). Urwany lot: pokolenie inteligenckiej młodzieży powojennej w świetle listów $i$ pamiętników z lat 1945-1948. Kraków: Wydawnictwo Literackie. 
Szczepański, J. (Ed.). (1959). Wyksztatcenie a pozycja społeczna inteligencji: praca zbiorowa, t. I. Łódź: PWN.

Szczepański, J. (1963). Socjologiczne zagadnienia wyższego wykształcenia. Warszawa: PWN.

Tromly, B. (2014). Making the soviet intelligentsia: Universities and intellectual life under Stalin and Khrushchev. Cambridge: Cambridge University Press.

Wacquant, L. (1989). For a socio-analysis of intellectuals: On "Homo Academicus." Berkeley Journal of Sociology, (34), 1-29.

Webb, J., Schirato, T., \& Danaher, G. (2002). Understanding Bourdieu. London: Thousand Oaks: Sage.

Woskowski, J. (1958). Losy absolwentów historii Uniwersytetu Łódzkiego. In J. Szczepański (Ed.), Z badań klasy robotniczej i inteligencji. Lódź. Warszawa.

Zarycki, T. (2008). Kapital kulturowy: inteligencja $w$ Polsce $i$ w Rosji. Warszawa: Wydawnictwo Uniwersytetu Warszawskiego.

Publisher's note Springer Nature remains neutral with regard to jurisdictional claims in published maps and institutional affiliations.

Agata Zysiak Assistant Professor at the University of Łódź, is a sociologist of culture. Her research interests include historical sociology, biography, and modernity in Eastern Europe. She is the author of the awardwinning book about the socialist university and upward mobility in postwar Poland, Punkty za pochodzenie (Points for Social Origin) (2016), and co-author of the recent volume From Cotton and Smoke: The Industrial City and Discourses of Asynchronous Modernity 1897-1994 (2018). She held a fellowship at the Institute for Advanced Studies, Princeton, in 2017-18. Currently she also works at University of Warsaw, where she conducts comparative research on the working class in Detroit and Lodz. 